\title{
Review
}

\section{Is Multiple System Atrophy a Prion-like Disorder?}

\author{
Kurt A. Jellinger $1, * \mathbb{C}$, Gregor K. Wenning ${ }^{2} \mathbb{D}$ and Nadia Stefanova ${ }^{2} \mathbb{D}$ \\ 1 Institute of Clinical Neurobiology, 1150 Vienna, Austria \\ 2 Division of Neurobiology, Department of Neurology, Medical University of Innsbruck, \\ 6020 Innsbruck, Austria; gregor.wenning@i-med.ac.at (G.K.W.); Nadia.Stefanova@i-med.ac.at (N.S.) \\ * Correspondence: kurt.jellinger@univie.ac.at; Tel./Fax: +43-1-5266534
}

check for

updates

Citation: Jellinger, K.A.; Wenning, G.K.; Stefanova, N. Is Multiple System Atrophy a Prion-like Disorder? Int. J. Mol. Sci. 2021, 22, 10093. https:// doi.org/10.3390/ijms221810093

Academic Editor: Daniel Taillandier

Received: 12 August 2021

Accepted: 16 September 2021

Published: 18 September 2021

Publisher's Note: MDPI stays neutral with regard to jurisdictional claims in published maps and institutional affiliations.

Copyright: (C) 2021 by the authors. Licensee MDPI, Basel, Switzerland. This article is an open access article distributed under the terms and conditions of the Creative Commons Attribution (CC BY) license (https:// creativecommons.org/licenses/by/ $4.0 /)$.

\begin{abstract}
Multiple system atrophy (MSA) is a rapidly progressive, fatal neurodegenerative disease of uncertain aetiology that belongs to the family of $\alpha$-synucleinopathies. It clinically presents with parkinsonism, cerebellar, autonomic, and motor impairment in variable combinations. Pathological hallmarks are fibrillary $\alpha$-synuclein ( $\alpha$ Syn)-rich glial cytoplasmic inclusions (GCIs) mainly involving oligodendroglia and to a lesser extent neurons, inducing a multisystem neurodegeneration, glial activation, and widespread demyelinization. The neuronal $\alpha$ Syn pathology of MSA has molecular properties different from Lewy bodies in Parkinson's disease (PD), both of which could serve as a pool of $\alpha$ Syn (prion) seeds that could initiate and drive the pathogenesis of synucleinopathies. The molecular cascade leading to the "prion-like" transfer of "strains" of aggregated $\alpha$ Syn contributing to the progression of the disease is poorly understood, while some presented evidence that MSA is a prion disease. However, this hypothesis is difficult to reconcile with postmortem analysis of human brains and the fact that MSA-like pathology was induced by intracerebral inoculation of human MSA brain homogenates only in homozygous mutant 53T mice, without production of diseasespecific GCIs, or with replication of MSA prions in primary astrocyte cultures from transgenic mice expressing human $\alpha$ Syn. Whereas recent intrastriatal injection of Lewy body-derived or synthetic human $\alpha$ Syn fibrils induced PD-like pathology including neuronal $\alpha$ Syn aggregates in macaques, no such transmission of $\alpha$ Syn pathology in non-human primates by MSA brain lysate has been reported until now. Given the similarities between $\alpha$ Syn and prions, there is a considerable debate whether they should be referred to as "prions", "prion-like", "prionoids", or something else. Here, the findings supporting the proposed nature of $\alpha$ Syn as a prion and its self-propagation through seeding as well as the transmissibility of neurodegenerative disorders are discussed. The proof of disease causation rests on the concordance of scientific evidence, none of which has provided convincing evidence for the classification of MSA as a prion disease or its human transmission until now.
\end{abstract}

Keywords: multiple system atrophy; $\alpha$-synuclein; prion-like spreading; neurodegeneration

\section{Introduction}

Multiple system atrophy (MSA) is a fatal adult-onset neurodegenerative disorder of uncertain aetiology with a mean incidence of 0.6-0.7 cases per 100,000 person-years. It is clinically featured by various combinations of parkinsonism, cerebellar impairment, autonomic and motor dysfunction due to the degeneration of striatonigral, olivopontocerebellar, and autonomic nervous systems [1-4] caused by the self-templated misfolding of the protein $\alpha$-synuclein ( $\alpha$ Syn). The core pathological features are fibrillary $\alpha$ Syn-rich glial cytoplasmic inclusions (GCI) mainly involving oligodendroglia [5]. Misfolded $\alpha$ Syn aggregates are also present in Parkinson's disease (PD) and Lewy body dementia (DLB), which are summarized as $\alpha$-synucleinopathies [6]. In contrast to PD and DLB, where aggregated $\alpha$ Syn predominantly accumulates within astrocytes and neurons, in MSA, it mainly accumulates within oligodendroglia and to a lesser extent in neurons [7-9]. The pathogenic cascade leading to $\alpha$ Syn aggregation and the neurodegeneration of this oligodendroglioneuronal proteinopathy is poorly understood $[10,11]$, but recent studies 
elucidated the early cellular dysfunction in MSA indicating both increased susceptibility to oxidative stress and disease-related translocation of $\alpha$ Syn to the cell nucleus [12], while others demonstrated mislocalization of myelin-associated oligodendrocyte basic protein (MOBP) and huntingtin protein 1 (HIP1) due to DNA methylation interacting with $\alpha$ Syn in the oligodendrocyte as a pathogenic way of MSA [13]. Converging evidence suggests a "prion-like" spreading of misfolded $\alpha$ Syn "strains" as a pathogenic key event [14-25], while others suggested that MSA is a prion disease [26-29]. The prion hypothesis of human synucleinopathies and the question of whether $\alpha$ Syn is a prion or prion-like are a matter of continuous discussion [15,30-42]. In both PD and MSA, the debate for and against considering them as prion diseases simply from a prionoid perspective-is ongoing [22,43-47]. This is a critical review of the current data about the prion hypothesis of MSA and other synucleinopathies.

\section{Self-Propagation of Prionoids}

In a series of articles, Prusiner et al. assessed whether $\alpha$ Syn aggregates may act as a prion disease $[26,27,29,46,48,49]$. A prion was originally described as "a small proteinaceous infectious particle which is resistant to interaction by most procedures that modify nucleic acids" [50]. Later the definition was updated to "proteins that acquire alternative conformations that become self-propagating", leaving out the requirement for infectivity [51], while, according to others, prions are composed of self-propagating assemblies of misfolded cellular proteins that encode information, generate neurotoxicity, and evolve and adapt in vivo [52]. The prion hypothesis was initially suggested to be incompatible with the observation that the disease agent was capable of inducing multiple disorders in the absence of nucleic acid [53]. This question was resolved with the introduction of the strain hypothesis, which suggests that a disorder is determined by the conversion of the cellular prion protein $\left(\mathrm{PrP}^{\mathrm{C}}\right)$ into the pathologic isoform $\mathrm{PrP}^{\mathrm{Sc}}$ rather than by maturation in a real viral genome [54,55]. In prion diseases, biochemically different species may be responsible for propagation and toxicity. Recent research has shown that in MSA and other neurodegenerative diseases, the protein misfolding is not exclusive to the conversion of $\operatorname{PrP}^{\mathrm{C}}$ into $\operatorname{PrP}^{\mathrm{Sc}}[56,57]$. The recognition that strains have a profound impact across neurodegenerative diseases has provided further insight into their pathogenesis $[58,59]$. Many observations strengthened the notion that proteins like $\beta$-amyloid (A $\beta)$, tau, and $\alpha$ Syn behave like prions. EM structures of recombinant fibrils or patient-derived aggregates containing these proteins show templated misfolding implying that the same mechanisms that induce $\mathrm{PrPS}^{\mathrm{Sc}}$ aggregation also enable the self-templating of these pathologic proteins $[56,60]$. Similarities are present with the $\alpha$ Syn protein responsible for MSA and other synucleinopathies, and mounting genetic, structural, and biological data support the hypothesis that MSA $\alpha$ Syn prions are distinct from those found in LB diseases, including PD [60]. Carboxy truncations of $\alpha$ Syn promote both its aggregation and toxicity [61]. Specific carboxy truncated forms of $\alpha$ Syn have been detected by immunostaining with antibodies that specifically react with their precise forms showing their specific distribution [41]. In DLB, neuronal inclusions in the SN and amygdala were positive for $\alpha$ Syn cleaved after residues 103,119, 122, and 125, whereas in MSA GCIs $\alpha$ Syn truncated at residues 103, 115, 119, and 125 were present. In the pontine nuclei, MSA NCIs were reactive to the $\alpha$ Syn $x-122$ neo-epitope but negative for 103 cleavage. These data demonstrate significant disease-, region-, and cell type-specific differences in carboxyterminal $\alpha$ Syn in pathological inclusions that may contribute to their distinct strain-like prion properties in the different synucleinopathies, but they also may be related to different prion-like conformational species with various sequences responsible for cleavage [40]. Proteinase $\mathrm{K}$ digestion is used to demonstrate the signature of different prion-like protein strains. Altered cleavage profiles due to structural differences are consistent with MSA $\alpha$ Syn profiles structurally different from those in DLB [62]. The differences of the $\alpha$ Syn strains are responsible for the heterogeneity of pathological features and disease processes 
among synucleinopathies [63] and have been recently proposed to contribute to the more aggressive progression of MSA [64].

Using this modern definition, $\alpha$ Syn aggregates can be classified as prions as they are able to self-multiply during disease, leading to cellular transmission and the spreading of protein aggregates $[65,66]$. Endogenous $\alpha$ Syn can aggregate through a homotypic (self-seeding) or a heterotypic seeding $[67,68]$, the latter referring to the involvement of other proteins in the initiation of $\alpha$ Syn aggregation [69,70]. The essential point of the prion hypothesis is the notion that self-propagating $\alpha$ Syn aggregates are able to escape from a cell, enter a neighboring one, and then act as a seed to introduce the aggregation of $\alpha$ Syn in the recipient cell [71]. The internalization of the pathogenic conformation of $\alpha$ Syn facilitates its spreading from neuron to neuron [72,73]. $\alpha$ Syn oligomers are internalized primarily through endocytosis [74]. The seeding activity of pathological $\alpha$ Syn species is thought to mediate a process of mutation-dependent aggregation, self-templated propagation of the pathological protein state [32,75]. Intraneuronal $\alpha$ Syn aggregates are triggered by internalized small fibers that do not contact membranes directly, suggesting that this mechanism is relevant to the spreading of aggregated pathologies [76]. Although the molecular mechanisms responsible for spreading pathologic $\alpha$ Syn are poorly understood, a growing body of evidence indicates that de novo misfolding and/or neuronal internalization of aggregated $\alpha$ Syn facilitates conformational templating of endogenous $\alpha$ Syn monomers in a prion-like manner [77]. Recent studies demonstrating that cellular prion protein $\left(\mathrm{PrP}^{\mathrm{C}}\right)$ mediates $\alpha$ Syn uptake, localization, and toxicity in vitro and in vivo confirmed previous results which showed that $\operatorname{PrP}^{C}$ internalizes soluble misfolded $\alpha$ Syn, indicating its important role in its internalization required for the intercellular spread of $\alpha \mathrm{Syn}$ [78]. Cell intrinsic features also may play a critical role in the formation of pathologic $\alpha$ Syn, such as mechanisms that increase endogenous $\alpha$ Syn levels, selective expression profiles in distinct neuron types, altered function of proteins involved in $\alpha$ Syn synthesis and degradation, and oxidative stress. The cell-intrinsic mechanisms that trigger $\alpha$ Syn aggregation and facilitate the conversion of $\alpha$ Syn to a fibrillar pathway to assemble into Lewy bodies, and others, may be important for its self-propagation [79]. Aggregation and propagation in the brain and peripheral organs suggested that $\alpha$ Syn as a prionoid is transmitted from the periphery to the brain via specific pathways [47]. This non-cell-autonomous mechanism was suggested to be similar to that in prion diseases such as Creutzfeldt-Jakob disease, where the prion protein $(\operatorname{PrP})$ in its misfolded form catalyzes the conformational conversion of normal PrP into additional copies of the misfolded $\mathrm{PrP}\left(\mathrm{PrP}^{\mathrm{Sc}}\right)$ [80]. The ability of prions to self-propagate allows them to spread within host tissues and underlies the transmissible nature of the prion disorders with the capacity to spread between individuals or species [81]. Various proteins have been shown to spread between cells and tissues of the host (for reviews see [82-84]), but there is no clear evidence of transmission between individuals, at least by artificial or natural routes [85-87]. As the risk of clinical transmission of proteinopathies between humans is critically evaluated, the scenarios for PrP-based prion diseases and their many experimental models must be considered. Not all prion diseases can "spread" horizontally between individuals. Thus, human prion diseases are not contagious in this manner, in contrast to scrapie and others. PrP-based diseases can represent deadly examples of transmissible proteinopathies. However, the ability of an ordered protein assembly to propagate in vitro or in vivo does not necessarily mean that they are transmissible by any casual contacts or medical procedures, or even if they are, that a disease may definitely result from that transmission [86]. There is currently no evidence that $\alpha$ Syn-dependent PD or MSA can be transmitted from person to person $[37,85,88]$. Many scientists described such intermediate self-propagating protein states as "prion-like", while others prefer to simply call them all prions $[49,89]$. The proposed prion-like mechanisms (prionoid) would be restricted to proteins with or among adjacent cells [90], whereas others commented on certain similarities between prion and prionoid and the possibility of prion-like transmissibility of some prionoid strains [91]. Their role in the pathogenesis of neurodegenerative diseases has been critically reviewed [23,92]. 
This mechanism would include the misfolding (from $\alpha$-helix to $\beta$-sheet) of native proteins that aggregate into "seeds" that structurally have the capacity to corrupt proteins in their physiological conformation and induce their misfolding. Aggregated $\alpha$ Syn moreover can disrupt glial function, thus contributing to neurodegeneration through various pathways [93]. This process would spread in a chain reaction of misfolding and aggregation ranging from oligomers to large masses of pathologic proteins, leading to neurodegeneration, glial activation, and demyelination [94,95] (Figure 1).

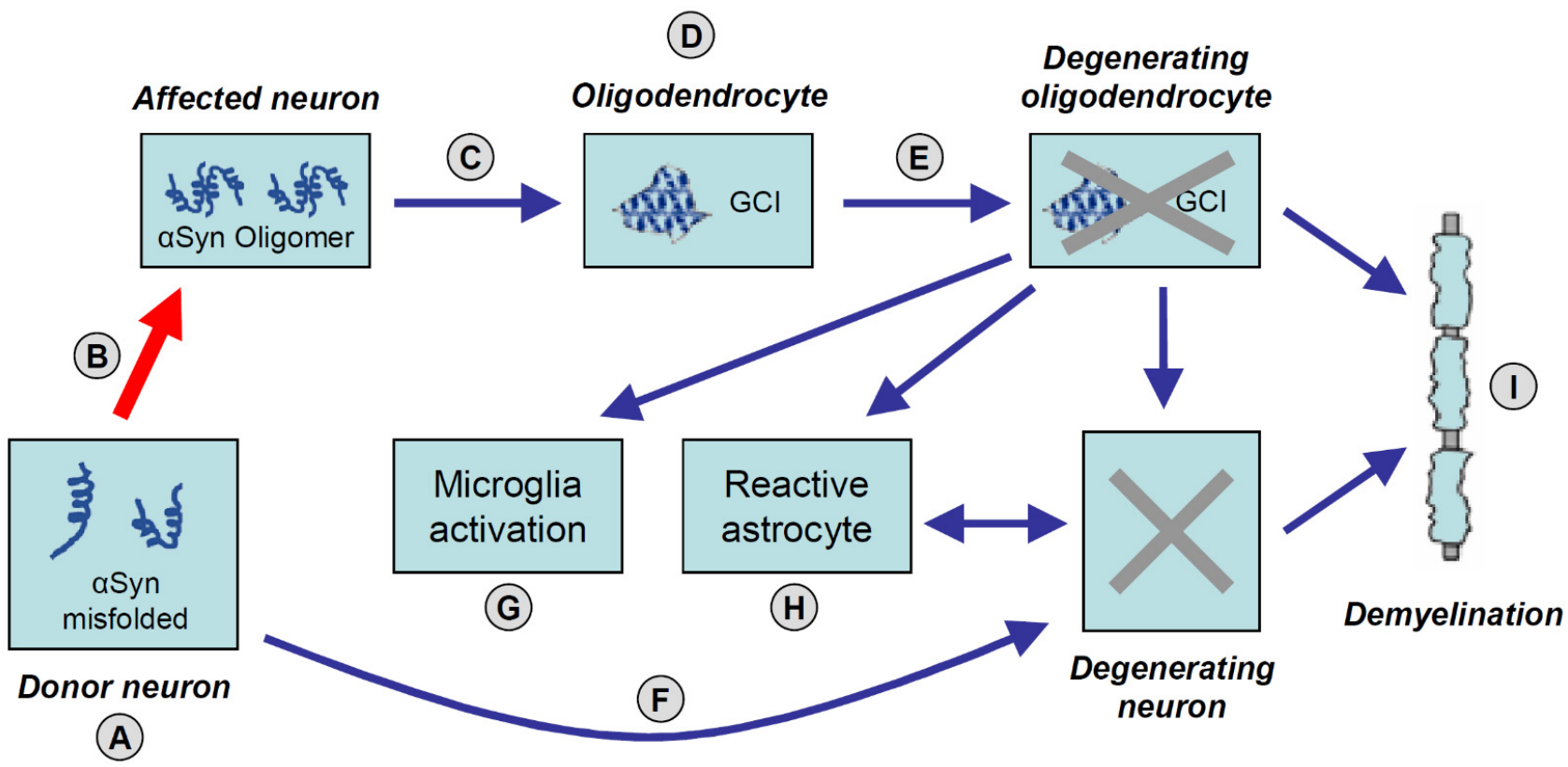

Figure 1. Suggested accumulation and spreading mechanisms of pathological $\alpha$-synuclein ( $\alpha$ Syn) leading to neurodegeneration in MSA. (A) Aggregation of $\alpha$ Syn as tetramers and oligomers in neurons. (B) "Prion-like" cell-to-cell spreading of abnormally folded $\alpha$ Syn via exosomes (red arrow). (C) $\alpha$ Syn aggregates and oligomers released from affected neurons into the extracellular space through exocytosis. (D) $\alpha$ Syn aggregation in oligodendroglial cytoplasm. (E) Formation of characteristic glial cytoplasmic inclusions (GCIs) in oligodendroglia containing $\alpha$ Syn and p25 $\alpha$. (F) Prionoid material can be transmitted directly across synapses causing neurodegeneration. (G) Activated micro-/astroglial cells by cytokines released from damaged oligodendrocytes and degenerating neurons. $(\mathbf{H})$ Aggregation of $\alpha$ Syn (or other prionoid material) in astrocytes that are also activated by neuronal loss. (I) Demyelination caused by damaged oligodendroglia and related to degenerating neurons.

It has been suggested to change the definition of prions to "proteinaceous nucleating particle", to avoid the infectious implication and to highlight the molecular action of the agents [83]. The term "propagon" has also been suggested to denominate these proteins that act like prions [96]. Both evidence of self-templating propagation in cellular cultures, animal models, and in humans are required to define MSA as a prion disease [97].

\section{In Vivo and In Vitro Data}

The theory that the prion-like mechanisms may underlie neurodegenerative disorders was supported by the demonstration of Lewy pathology after therapeutic transplantation in people with PD, which was discovered not only in the host neurons but also in grafted dopamine neurons about two decades after transplantation. It was hypothesized that prionlike transfer of $\alpha$ Syn might underlie the unexpected pathology in these patients [98-100]. Earlier work demonstrating the presence of extracellular $\alpha$ Syn in human plasma and cerebrospinal fluid suggested that $\alpha$ Syn could enter cells from extracellular space [101]. These results as well as many studies using cell culture and animal models gave support to the prion-like hypothesis of the intercellular transfer of $\alpha$ Syn $[20,27,102]$. In PD brains, $\alpha$ Syn accumulates within neurons and propagates from cell to cell in a prion-like manner [15]. 
Transmission of pathological $\alpha$ Syn (and tau) between anatomically connected brain regions underlies the stereotypical spread of these and other pathological proteins [59], but it is modulated by the selective vulnerability of cell types and predicted by networks analysis [103]. The spread of $\alpha$ Syn pathology from one cell to another not only within the central nervous system (CNS) and even from one nervous system structure to another in vivo as well as from peripheral locations (such as the gut or olfactory networks into the CNS [47]) has already been convincingly demonstrated $[14,20,27,98,104-107]$. Prion-like $\alpha$ Syn propagation has been widely studied in PD [18], where there is evidence of misfolded $\alpha$ Syn in neural cell cultures $[108,109]$. This spreading pattern resembling that of prions has led to the concept of prion-like propagation of $\alpha$ Syn and tau [52,98,110-112], and the A $\beta$-induced acceleration of tau pathology spreading and its association with prion protein $[113,114]$ (for rev. see [23,39]). This hypothesis in humans is well documented in AD [115], although it is still a hypothesis, like the amyloid cascade [52].

The inoculation of wild-type (WT) mice with synthetic mouse $\alpha$ Syn pre-formed fibrils (PFFs) into striatum induced widespread $\alpha$ Syn pathology and dopaminergic neuronal loss in the substantia nigra compacta, whereas $\alpha$ Syn knockout mice inoculated with PFFs did not develop $\alpha$ Syn pathology [68]. This suggested that endogenous $\alpha$ Syn was necessary to propagate $\alpha$ Syn pathology. Intracerebral injection of sarkosyl-insoluble $\alpha$ Syn homogenates from DLB brain induced $\alpha$ Syn pathology in WT mice [116]. While exogenous human $\alpha$ Syn disappeared a week after inoculation, endogenous mouse $\alpha$ Syn was converted into a pathological form and accumulated in neurons through a prion-like mechanism at three months post-inoculation [117]. Propagation of hyperphosphorylated $\alpha$ Syn occurred along neuronal circuits and involved trans-synaptic transport mechanisms, suggesting that exogenous pathological $\alpha$ Syn can propagate in a neuron-to-neuron manner, but was not associated with motor deficits. A recent review described modeling $\alpha$ Syn propagation with PFF injections and the outcome of these models [118]. The self-propagation of $\alpha$ Syn oligomers in vitro, however, is not sufficient to define them as prions, because they show "seeding" activity rather than infectivity of $\alpha$ Syn [37]. Disease-associated $\alpha$ Syn adopts a conformation that induces it to form oligomers and fibrils with reduced solubility. They become hyperphosphorylated, and contribute to the spatiotemporal spreading of pathology in the CNS, but how the uptake of $\alpha$ Syn varies with the size of oligomers is less clear [74]. The binding of $\alpha$ Syn oligomers to the gap junction protein connexin-32 (Cx32) has been shown to facilitate protein uptake and transfer in neurons and oligodendrocytes [119]. Oligodendroglial p25 $\alpha$ is suggested to be responsible for generating a highly pathological $\alpha$ Syn strain in MSA [120]. Oral or intravenous transmission of $\alpha$ Syn fibrils to TgM83+/mice induces a progressive synucleinopathy associated with overt motor dysfunction and pathological deposition of $\alpha$ Syn aggregates within the brain [121]. Hemizygous TgM83 mice do not develop $\alpha$-synucleinopathy spontaneously, allowing them to detect disease transmission following extended incubation periods of more than one year postinoculation. Inoculation studies using homogenates from MSA brain regions lacking detectable $\alpha$ Syn pathology also transmitted neurological lesions to mice indicating that $\alpha$ Syn prion formation precedes neuropathology in the brain, suggesting that the lesions are not limited to affected brain regions [25]. This clearly indicates that $\alpha$ Syn fibrils, like prions, can neuroinvade the CNS after a single oral or intravenous challenge and cause neuropathology. These findings are in agreement with studies demonstrating a cerebral synucleinopathy in transgenic $(\mathrm{tg})$ mice following a peripheral inoculation with $\alpha \mathrm{Syn}$ aggregates [122-125]. Peripheral application of $\alpha$ Syn fibrils that can induce cerebral $\alpha$ Syn pathology suggests that they possess the innate ability to propagate from the periphery to the brain $[47,126]$. This appears important for understanding the pathogenesis of PD, as it has been speculated that synucleinopathies may originate in the gut before propagating to the brain in a prion-like manner [127].

The intrastriatal injection of PFF $\alpha$ Syn in rodent brains induced a PD-like propagation of Lewy body (LB) pathology together with significant nigrostriatal neurodegeneration. The injection of exogenous $\alpha$ Syn PFFs into the putamen of non-human primates (cynomol- 
gus monkeys) resulted in a significant reduction in dopaminergic neurons in the ipsilateral substantia nigra $(-29.3 \%)$, downregulation of the dopamine markers tyrosine hydroxylase and Nurr1, associated with LB-like intraneuronal $\alpha$ Syn-positive inclusions; all taken together indicative of early PD [67]. Previous studies using $\alpha$ Syn containing LB-enriched fractions from PD patients into the striatum of macaques showed similar results with the accumulation of $\alpha$ Syn pathology within host neurons and neurodegeneration beginning in dopaminergic terminals, over the course of 12-14 months involving related regions in a PD-like distribution [128]. The injection of synthetic human $\alpha$ Syn fibrils in the striatum of macaque monkeys (Macaca fuscata) showed into the left striatum of Macaca fuscata induced LBs, massive $\alpha$ Syn + NVIs and neurites in the left striatum, some NCIs and neurites in the left SN and bilateral frontal cortex associated with mild neuronal loss and gliosis, while other brain areas were not affected. These results indicated that abnormal $\alpha$ Syn fibrils propagate throughout the brain via projection, association, and commissural fibers, though the progression of $\alpha$ Syn pathology was limited [129]. The intracerebral injection of synthetic $\alpha$ Syn fibrils into adult WT marmoset brains caused abundant $\alpha$ Syn pathologies within only three months post-injection. Robust LB-like inclusions were formed in tyrosine hydroxylase-positive neurons associated with a significant decrease in these neurons suggesting the retrograde spreading of abnormal $\alpha$ Syn and its neurotoxicity [130]. These studies indicate that exogenous $\alpha$ Syn is internalized by dopaminergic terminals, spread to the substantia nigra, and induces PD-like pathology including $\alpha$ Syn aggregation and nigral neuronal degeneration. This supports the ability of abnormal $\alpha$ Syn to propagate to distant brain regions and to trigger neurodegeneration.

\section{Prion-Like Properties of $\alpha$ Syn}

$\alpha$ Syn has a prion-like property, the propensity to aggregate, that converts its physiological protein conformation into a pathogenic one, forming disease-causing fibrils. The aggregation of these fibrils and subsequent inclusion formations are suggested to interfere with vesicular trafficking and organelle functions in neurons [131]. However, the applicability of the prion hypothesis in $\alpha$-synucleinopathies remains controversial [45,97]. Although some research groups showed the "infectious" activity of LB extracts from PD brains in mice and also in monkeys [128], demonstrating the prion propensities of $\alpha$ Syn assemblies [44], so far there is no evidence of pathologic $\alpha$ Syn aggregate transmission between individuals leading to the prion-like definition to make a distinction between this protein and actively infectious prions [132]. Several studies demonstrated that pathological $\alpha$ Syn aggregates of GCIs have distinct conformational and biological activities both in vitro and in vivo from those of LBs $[26,133,134]$. This indicates that $\alpha$ Syn from MSA has a different conformation and a much higher spreading potential than that from PD [133,134]. Injections of MSA brain lysates failed to replicate the oligodendroglial $\alpha$ Syn pathology, raising questions about the pathogenesis of oligodendroglial $\alpha$ Syn aggregates in MSA [72] WT mice injected with mouse $\alpha$ Syn PFFs developed neuronal $\alpha$ Syn pathology after short post-injection (PI) intervals on the scale of weeks, while oligodendroglial $\alpha$ Syn pathology emerged after longer PI intervals of several months [135]. The protease activity profiles of oligodendrocytes may be distinctive from that of neurons, resulting in the differential $\alpha$ Syn cleavage products responsible for their higher pathogenicity of oligodendroglial $\alpha$ Syn prion-like strains. This would be consistent with a low $\alpha$ Syn expression in oligodendrocytes [136], but that $\alpha$ Syn pathology predominantly spreads in these cells in MSA. It is preferentially propagated in oligodendrocytes despite their lower $\alpha$ Syn expression levels due to a favorable cleavage environment that produces the more potent strains. Aberrant protease activities in MSA could exacerbate this process, but this should be confirmed by future experiments [41]. Both soluble and insoluble fractions of MSA extracts have robust seeding activity, while only the insoluble fraction of PD extracts displayed seeding activity. MSA-seeded inclusions differed from PD-seeded inclusions persisting upon propagation of aggregation to second-generation biosensor cells. It was concluded that PD and MSA feature $\alpha$ Syn conformers with distinct biochemical properties that can be transmitted to 
$\alpha$ Syn monomers in a cell system. These findings are consistent with the assumption that distinct $\alpha$ Syn strains underlie PD and MSA [137]. The observation that familial Parkinson's point mutation abolishes MSA prion replication also established that MSA $\alpha$ Syn "prions" are conformationally distinct from the misfolded $\alpha$ Syn in PD [48].

The intracerebral injection of insoluble $\alpha$ Syn into WT mice induced prion-like propagation of phosphorylated $\alpha$ Syn pathology even one month after injection, while injection into $\alpha$ Syn-knockout mice failed to induce any pathology [71]. Abundant oligodendroglial $\alpha$ Syn pathology in white matter developing later was reminiscent of that in MSA. Comparison between young and aged mice injected with mouse $\alpha$ Syn PFFs revealed that PI intervals rather than aging corresponded with oligodendroglia $\alpha$ Syn aggregation in MSA [135]. While these studies indicate that oligodendroglial $\alpha$ Syn pathology can be replicated in WT mice and provide novel insights into the pathological mechanisms of oligodendroglial $\alpha$ Syn aggregations in MSA, the seeded assembly of recombinant human $\alpha$ Syn in vitro did not replicate the structures of $\alpha$ Syn filaments from MSA. This suggests that additional, as yet unknown factors may be essential for the prion-like spreading of $\alpha$ Syn proteinopathies [138]. In MSA, intracerebral inoculation studies in non-human primates, to the best of our knowledge, have not been performed yet.

Homozygous tg mice expressing human $\alpha$ Syn with A53T mutation, termed TgM83+/+ mice, spontaneously develop motor deficits at about one year of age, along with widespread $\alpha$ Syn pathology [139]. Inoculations of young asymptomatic TgM83+/+ mice with brain homogenates from old TgM83+/+ mice induced motor dysfunction [29]. Both intracerebral and peripheral inoculation of brain homogenates from MSA but not from PD patients, were able to produce $\alpha$ Syn pathology in TgM83+/ - (hemizygous for the transgene), but not TgM83-/ - WT mice, suggesting that different $\alpha$ Syn strains may have different seeding characteristics $[27,29,48]$. This suggests that $\alpha$ Syn strains different from those observed in PD may be the causative mechanism of MSA [73,137]. It further means that TgM83 mice probably cannot be considered a valid animal model for MSA. This was supported by the fact that Lewy pathology but not MSA-typical GCI pathology was induced by inoculation in $\alpha$ Syn TgM83+/ - hemizygous mice, but not in WT mice, suggesting that the A53T $\alpha$ Syn mutation in the SNCA gene plays a critical role in $\alpha$ Syn spreading and self-propagation in this model system. A53T mutation is probably not involved in MSA, but the model is nevertheless responsive to MSA homogenates and, therefore, can be used to study how MSA $\alpha$ Syn adapts, which could be a valid research question, comparable to studies in the prion field where, e.g., hamster prions have been inoculated into mice. Homogenate from diseased MSA patients readily transmits neurodegeneration to TgM83+/- mice [29]. This provided the opportunity to determine if $\alpha$ Syn adopts an alternative confirmation that undergoes self-propagation, which was suggested to become a prion. Nineteen MSA patient samples from three continents transmitted disease to TgM83+/ - mice, while those from PD patients did not [26]. Using human embryonic kidney (HEK293T) cells expressing mutated $\alpha$ Syn fused to a yellow fluorescent protein ( $\alpha$ Syn140*A53T-YFP). They infected the cells with $\alpha$ Syn isolated from MSA brains but not from PD samples [26]. Studies showing conformational and biological differences between aggregated $\alpha$ Syn species in $\mathrm{PD}$ and MSA indicated that the cellular environment affects the aggregation process of $\alpha$ Syn $[26,133,134]$. The existence of two distinct strains in MSA and PD patients is consistent with the findings that $\alpha$ Syn misfolding into distinct conformations produces differing pathophysiological effects $[140,141]$. These and other findings suggest that specific strains of $\alpha$ Syn aggregates are responsible for each disease, and may underlie the pathological and clinical diversity of $\alpha$-synucleinopathies $[142,143]$. The inoculation of tg mice with different strains of recombinant or brain-derived $\alpha$ Syn aggregates produced clinically and pathologically distinct diseases [56], suggesting that both prion-like spreading and selective vulnerability contribute to the temporal and spatial evolution of $\alpha$ Syn pathology within the brain. Thus, pathogenic $\alpha$ Syn exhibits key hallmarks of prion strains, which provides evidence that disease heterogeneity among the synucleinopathies is caused by distinct $\alpha$ Syn strains $[39,63]$. 
The mechanisms of the seeding of $\alpha$ Syn pathology in the nervous system are defined by several factors that can differently influence the pathology among strains, thereby causing distinct disease entities $[60,64,144,145]$. Therefore, it may be necessary to use disease-specific aggregates in such experiments. In prion disorders, approaches targeting $\mathrm{PrP}^{\mathrm{C}}$ oligomers are developed based on the observation that only oligomers, not monomers, are infectious [22].

\section{Multiple System Atrophy: A "Prion" Disease?}

There are several challenges to the hypothesis that MSA is a prion-disease. First, endogenous WT $\alpha$ Syn is insufficient to propagate $\alpha$ Syn pathology and mutated $\alpha$ Syn is needed as a template. Tg Nbm mice inoculated with the PFFs of brain homogenates from MSA brains developed "prions", while the control sample did not. Transmission of $\alpha$ Syn "prions" to a second synucleinopathy model and their ability to propagate between two distinct mouse lines while retaining strain-specific properties were suggested to provide compelling evidence that MSA is a prion disease [28]. Another recent study showed that MSA brain lysates contain sufficient seeding activity to induce $\alpha$ Syn inclusion pathology following neonatal injection in TgM83+/- mice, probably inducing several mechanisms besides conformational templating such as the disruption of normal protein homeostasis and neuroinflammatory reactions. $\mathrm{Tg}\left(\mathrm{SNCA}^{*} \mathrm{~A} 53 \mathrm{~T}(+/+)\right) \mathrm{Nbm}$ mice developed $\alpha \mathrm{Syn}$ pathology in neurons and astrocytes throughout the limbic system, which is in contrast to MSA-inoculated TgM83(+/-) mice, which developed exclusively neuronal $\alpha$ Syn aggregations in the hindbrain that caused motor deficits with advanced disease. In crossover experiments, TgM83(+/-) mice inoculated with mouse-passaged control samples had no effect. The same was seen in that mouse-passaged MSA samples induced $\alpha$ Syn formation in $\mathrm{Tg}\left(\mathrm{SNCA}^{*} \mathrm{~A} 53 \mathrm{~T}(+/+)\right) \mathrm{Nbm}$ mice, but not in controls. The confirmed transmission of $\alpha$ Syn "prions" to a second synucleinopathy model and the ability to propagate prions between two distinct mouse lines while retaining strain-specific properties were suggested to provide compelling evidence that MSA is a prion disease [28]. However, these and other transmission studies could not explain why in MSA $\alpha$ Syn pathology predominantly accumulates in oligodendroglia as MSA-derived $\alpha$ Syn does not have the ability to induce strain-like cell-specific $\alpha$ Syn aggregation. The intrinsic properties of the A53T $\alpha$ Syn in the TgM83 mouse model have been shown to dominate over any strain features harbored by misfolded $\alpha$ Syn in MSA brains [146]. Previous studies indicated that the "prion-like" progression of synucleinopathy in TgM83 mice depends on the mouse genotype (levels of $\alpha$ Syn expression by the mouse) and type of inoculum [147]. Replication of MSA "prions" in primary astrocyte cultures from TG mice expressing human $\alpha$ Syn showed that human $\alpha$ Syn forms distinct inclusion morphologies and propagates within cultured Tg astrocytes exposed to MSA $\alpha$ Syn. This indicates that $\alpha$ Syn expression dominates the tropism of inclusion formation in certain cells, elucidating the role of astrocytes in the pathogenic mechanism of MSA neurodegeneration [148].

Furthermore, GCIs, the morphological hallmarks of MSA, have never been identified in WT mouse brains inoculated with MSA-derived $\alpha$ Syn [29]. In fact, $\alpha$ Syn aggregates ("prions") derived from MSA patients generated a neurodegenerative pattern that is atypical for MSA [37]. These, and other findings, indicate that $\alpha$ Syn in MSA may be different from that in PD in "prion-like" properties. The fact that the in vivo phenotype has been observed only from inoculating MSA samples into TgM83+/ - mice, but not into WT mice [26] needs further investigation in order to better elucidate this particular issue. However, recent studies have shown that MSA "prions" retain strain specificity after serial propagation in two different $\operatorname{Tg}\left(\mathrm{SNCA}^{*} \mathrm{~A} 53 \mathrm{~T}\right)$ mouse lines. Moreover, the mouse-passaged MSA samples induced $\alpha$ Syn motor deficits despite showing $\alpha$ Syn pathology $[68,116]$. Tg mice expressing WT $\alpha$ Syn developed $\alpha$ Syn deposition at six months of age but no motor deficits [72]. Second, phosphorylated $\alpha$ Syn aggregates, the morphological hallmarks of MSA, were not detected in oligodendrocytes in MSA-inoculated TgM83+/ - mice [26,72]. Third, the intracerebral injection of homogenates from spinal cord tissue from naive motor-impaired 
TgM83+/+ mice induced robust $\alpha$ Syn pathology that mimics the prion-like pathological changes that occur in TgM83 mice when purified $\alpha$ Syn PFFs are injected to accelerate disease onset, suggesting non-prion-type transmission in A53 / $\alpha$ Syn tg mice [149]. Fourth, while $\alpha$ Syn strains may exist, no study has definitely propagated patient-derived seeds from cell-to-cell or mouse-to-mouse, nor fully characterized $\alpha$ Syn strains from MSA vs. PD [137]. Furthermore, they have failed to propagate distinct $\alpha$ Syn conformers in clonal lines as has been shown for tau [150], because aggregate-containing clones lose their aggregation state over time. The variety of seeds, animal models, and methodologies currently prevents clear conclusions regarding $\alpha$ Syn-related spreading and toxicity, as well as translation of preclinical findings to human disease [38]. In recent years, many studies have shown that prion-like proteins share not only the prion replication paradigm but also the specific ability to aggregate in different conformations, i.e., strains, with relevant clinical, pathological, diagnostic, and therapeutic implications, related to the molecular basis of the strain phenomenon in prion and prion-like proteins [39]. To confirm the existence of bona fide $\alpha$ Syn prion strains, it will be necessary to test whether distinct structures propagate through living systems and produce consistent pathology as do tau and PFFs. Further studies will be necessary to define the species that induce $\alpha$ Syn aggregation.

Another problem is the relation between $\operatorname{PrP}^{\mathrm{C}}$ and $\alpha \mathrm{Syn}$. $\operatorname{PrP}^{\mathrm{C}}$ knockdown in neuroblastoma cells was shown to attenuate the uptake of recombinant $\alpha$ Syn oligomers with a similar effect observed when comparing $\alpha$ Syn uptake in mouse primary hippocampal neurons, prepared from WT or $\mathrm{PrPC}^{\mathrm{C}}$ knockout mice. The latter developed lower levels of $\alpha \mathrm{Syn}$ aggregates in the cortex, striatum, thalamus, and hippocampus, suggesting that $\operatorname{PrP}^{\mathrm{C}}$ may facilitate the uptake and aggregation of $\alpha$ Syn oligomers [151]. They further showed that the replication of scrapie prions was blocked by $\alpha$ Syn oligomers [152], providing a possible explanation for the observation that Creutzfeldt-Jakob disease patients have a more protracted disease course when there is concomitant synucleinopathy [153]. However, another study found no evidence of binding between $\operatorname{PrP}^{\mathrm{C}}$ and $\alpha$ Syn oligomers and noted that $\operatorname{PrPC}^{\mathrm{C}}$ neither binds to $\alpha$ Syn oligomers nor mediates their detrimental effects [154]. It could be suggested that there may be different species of $\alpha$ Syn oligomers, which have a different binding capacity with $\mathrm{PrPC}^{\mathrm{C}}$, and it is possible that future studies could demonstrate that both $\mathrm{PrP}^{\mathrm{C}}$-dependent and -independent pathways could play a role in the pathogenesis of synucleinopathies [155]. Accordingly, aggregated $\alpha$ Syn may be potent in the cross-seeding of prion protein misfolding and aggregation in vitro, producing self-replicating states that can lead to prion diseases upon serial passaging in WT animals [156]. On the other hand, the presence of $\mathrm{PrP}^{\mathrm{Sc}}$ was required to promote the efficient internalization and spreading of abnormal $\alpha$ Syn between cells. However, recent studies showed that $\operatorname{PrP}^{\mathrm{Sc}}$ was able to efficiently propagate in the brain of animals even in the absence of $\alpha$ Syn, suggesting that this protein may not act as a key modulator of prion propagation. This suggests that $\alpha$ Syn may take part in this process of self-propagation but is not specifically required for sustaining prion conversion and propagation [157]. Prion strains can interfere with each other, influencing the emergence of a dominant strain, and both environmental and host factors may influence the evolution and distribution of prion strains within a population [158]. Moreover, gene analyses have shown that the homozygous state of positions 129 in the PRNP gene is not a risk factor for MSA and no other variants in the PRNP gene were associated with increased risk for MSA [159]. A review of the clinical histories of patients, who had died of MSA or PD, showed no evidence of neurosurgical transmission [160]. Furthermore, studies of couples whose spouses had autopsy-confirmed PD, PSP, or MSA, did not suggest an increased risk of $\alpha$-synucleinopathy development in the other spouses [161,162]. Up to the present, there is no evidence of iatrogenic transmission of autopsy-confirmed MSA cases. The current absence of evidence, however, is not evidence of the absence of human transmission of misfolded proteins other than prions and $A \beta$. In view of the importance of this question, the potential for non-invasive human transmission of proteinopathic neurodegenerative disorders needs further research [163] before any conclusion can be drawn [23]. 
In conclusion, one may postulate that even if the prion-like spreading of $\alpha$ Syn in experimental model systems may justify the view that the progression of neurodegeneration in MSA reflects the cell-to-cell spread of pathological $\alpha$ Syn, this is not sufficient to define MSA as a classical prion disease. After the injection of $\alpha$ Syn fibrils into the olfactory bulb of WT mice, despite the transneuronal spreading of $\alpha$ Syn aggregates to over 40 other brain regions, even at 18 months PI, there was no loss of mitral cells in the olfactory bulb. The lack of progression of $\alpha$ Syn pathology may be due to the compromise of the neuronal circuitry, and the activation of proteolytic mechanisms in resilient neurons may counterbalance the spread of pathogenic $\alpha$ Syn [164]. This underlines the interpretation that prion-like particles and prions are different entities, and that a more precise definition of both, which is capable of differentiating them from one another, is necessary [37]. Initial work on many prion studies has been hampered by incomplete or atypical transmissions, which were then refined with the advent of better animal models, often as tg mouse models. However, in view of the limited availability of human brain material, it is indispensable to develop new methodologies that enable the production of sufficient amounts of disease-specific aggregates for research in order to enable a deeper understanding of the molecular mechanisms underlying the pathogenesis of MSA — and other synucleinopathies-and to develop novel therapeutic strategies to target $\alpha$ Syn aggregation and disease progression in MSA. Therefore, future work may lead to better transmissions for MSA-causing $\alpha$ Syn conformers once a suitable animal model has been found.

Author Contributions: K.A.J. wrote the manuscript; G.K.W. contributed ideas and supervised the manuscript; N.S. contributed comments and suggestions for the manuscript revision. All authors have read and agreed to the published version of the manuscript.

Funding: The study was funded by the Society for the Promotion of Research in Experimental Neurology, Vienna, Austria.

Institutional Review Board Statement: Not applicable.

Informed Consent Statement: Not applicable.

Data Availability Statement: Data sharing not applicable.

Acknowledgments: The author thanks E. Mitter-Ferstl, for secretarial and graphical work.

Conflicts of Interest: The author declares no conflict of interest.

$\begin{array}{ll}\text { Abbreviations } \\ \text { A } \beta & \beta \text {-amyloid } \\ \alpha \text { Syn } & \alpha \text {-synuclein } \\ \text { CNS } & \text { central nervous system } \\ \text { DLB } & \text { Lewy body dementia } \\ \text { GCIs } & \text { glial cytoplasmic inclusions } \\ \text { LB } & \text { Lewy body } \\ \text { LB } & \text { Lewy body } \\ \text { MSA } & \text { Multiple system atrophy } \\ \text { PD } & \text { Parkinson's disease } \\ \text { PFFs } & \text { pre-formed fibrils } \\ \text { PI } & \text { post-injection } \\ \text { PrPC } & \text { cellular prion protein } \\ \text { PrPSc } & \text { pathologic PrP isoform } \\ \text { tg } & \text { transgenic } \\ \text { WT } & \text { wild-type }\end{array}$




\section{References}

1. Jellinger, K.A. Neuropathological findings in multiple system atrophy with cognitive impairment. J. Neural Transm. 2020, 127, 1031-1039. [CrossRef] [PubMed]

2. Krismer, F.; Wenning, G.K. Multiple system atrophy: Insights into a rare and debilitating movement disorder. Nat. Rev. Neurol. 2017, 13, 232-243. [CrossRef]

3. Gilman, S.; Wenning, G.K.; Low, P.A.; Brooks, D.J.; Mathias, C.J.; Trojanowski, J.Q.; Wood, N.W.; Colosimo, C.; Durr, A.; Fowler, C.J.; et al. Second consensus statement on the diagnosis of multiple system atrophy. Neurology 2008, 71, 670-676. [CrossRef] [PubMed]

4. Campese, N.; Fanciulli, A.; Stefanova, N.; Haybaeck, J.; Kiechl, S.; Wenning, G.K. Neuropathology of multiple system atrophy: Kurt Jellinger's legacy. J. Neural Transm. 2021. [CrossRef]

5. Trojanowski, J.Q.; Revesz, T. Proposed neuropathological criteria for the post mortem diagnosis of multiple system atrophy. Neuropathol. Appl. Neurobiol. 2007, 33, 615-620. [CrossRef]

6. Spillantini, M.G.; Goedert, M. Synucleinopathies: Past, present and future. Neuropathol. Appl. Neurobiol. 2016, 42, 3-5. [CrossRef]

7. Koga, S.; Dickson, D.W. Recent advances in neuropathology, biomarkers and therapeutic approach of multiple system atrophy. J. Neurol. Neurosurg. Psychiatry 2018, 89, 175-184. [CrossRef] [PubMed]

8. Kaji, S.; Maki, T.; Kinoshita, H.; Uemura, N.; Ayaki, T.; Kawamoto, Y.; Furuta, T.; Urushitani, M.; Hasegawa, M.; Kinoshita, Y.; et al. Pathological endogenous alpha-synuclein accumulation in oligodendrocyte precursor cells potentially induces inclusions in multiple system atrophy. Stem Cell Rep. 2018, 10, 356-365. [CrossRef] [PubMed]

9. Cykowski, M.D.; Coon, E.A.; Powell, S.Z.; Jenkins, S.M.; Benarroch, E.E.; Low, P.A.; Schmeichel, A.M.; Parisi, J.E. Expanding the spectrum of neuronal pathology in multiple system atrophy. Brain 2015, 138, 2293-2309. [CrossRef] [PubMed]

10. Monzio Compagnoni, G.; Di Fonzo, A. Understanding the pathogenesis of multiple system atrophy: State of the art and future perspectives. Acta Neuropathol. Commun. 2019, 7, 113. [CrossRef] [PubMed]

11. Jellinger, K.A. Multiple system atrophy: An oligodendroglioneural synucleinopathy. J. Alzheimers Dis. 2018, 62, 1141-1179. [CrossRef]

12. Herrera-Vaquero, M.; Heras-Garvin, A.; Krismer, F.; Deleanu, R.; Boesch, S.; Wenning, G.K.; Stefanova, N. Signs of early cellular dysfunction in multiple system atrophy. Neuropathol. Appl. Neurobiol. 2021, 47, 268-282. [CrossRef] [PubMed]

13. Bettencourt, C.; Miki, Y.; Piras, I.S.; de Silva, R.; Foti, S.C.; Talboom, J.S.; Revesz, T.; Lashley, T.; Balazs, R.; Viré, E.; et al. MOBP and HIP1 in multiple system atrophy: New alpha-synuclein partners in glial cytoplasmic inclusions implicated in the disease pathogenesis. Neuropathol. Appl. Neurobiol. 2021, 47, 640-652. [CrossRef] [PubMed]

14. Peelaerts, W.; Bousset, L.; Baekelandt, V.; Melki, R. Alpha-synuclein strains and seeding in Parkinson's disease, incidental Lewy body disease, dementia with Lewy bodies and multiple system atrophy: Similarities and differences. Cell Tissue Res. 2018, 373, 195-212. [CrossRef]

15. Vargas, J.Y.; Grudina, C.; Zurzolo, C. The prion-like spreading of alpha-synuclein: From in vitro to in vivo models of Parkinson's disease. Ageing Res. Rev. 2019, 50, 89-101. [CrossRef] [PubMed]

16. Vasili, E.; Dominguez-Meijide, A.; Outeiro, T.F. Spreading of alpha-synuclein and tau: A systematic comparison of the mechanisms involved. Front. Mol. Neurosci. 2019, 12, 107. [CrossRef] [PubMed]

17. Tarutani, A.; Arai, T.; Murayama, S.; Hisanaga, S.I.; Hasegawa, M. Potent prion-like behaviors of pathogenic alpha-synuclein and evaluation of inactivation methods. Acta Neuropathol. Commun. 2018, 6, 29. [CrossRef]

18. Visanji, N.P.; Brooks, P.L.; Hazrati, L.N.; Lang, A.E. The prion hypothesis in Parkinson's disease: Braak to the future. Acta Neuropathol. Commun. 2013, 1, 2. [CrossRef] [PubMed]

19. Dhillon, J.S.; Trejo-Lopez, J.A.; Riffe, C.; McFarland, N.R.; Hiser, W.M.; Giasson, B.I.; Yachnis, A.T. Dissecting alpha-synuclein inclusion pathology diversity in multiple system atrophy: Implications for the prion-like transmission hypothesis. Lab. Investig. 2019, 99, 982-992. [CrossRef]

20. Steiner, J.A.; Quansah, E.; Brundin, P. The concept of alpha-synuclein as a prion-like protein: Ten years after. Cell Tissue Res. 2018, 373, 161-173. [CrossRef]

21. Karpowicz, R.J., Jr.; Trojanowski, J.Q.; Lee, V.M. Transmission of alpha-synuclein seeds in neurodegenerative disease: Recent developments. Lab. Investig. 2019, 99, 971-981. [CrossRef] [PubMed]

22. Brás, I.C.; Outeiro, T.F. Alpha-synuclein: Mechanisms of release and pathology progression in synucleinopathies. Cells 2021, 10, 375. [CrossRef]

23. Jaunmuktane, Z.; Brandner, S. The role of prion-like mechanisms in neurodegenerative diseases. Neuropathol. Appl. Neurobiol. 2020, 46, 522-545. [CrossRef] [PubMed]

24. Veys, L.; Van Houcke, J.; Aerts, J.; Van Pottelberge, S.; Mahieu, M.; Coens, A.; Melki, R.; Moechars, D.; De Muynck, L.; De Groef, L. Absence of uptake and prion-like spreading of alpha-synuclein and tau after intravitreal injection of preformed fibrils. Front. Aging Neurosci. 2021, 12, 614587. [CrossRef] [PubMed]

25. Woerman, A.L.; Patel, S.; Kazmi, S.A.; Oehler, A.; Lee, J.; Mordes, D.A.; Olson, S.H.; Prusiner, S.B. Kinetics of alpha-synuclein prions preceding neuropathological inclusions in multiple system atrophy. PLoS Pathog. 2020, 16, e1008222. [CrossRef]

26. Prusiner, S.B.; Woerman, A.L.; Mordes, D.A.; Watts, J.C.; Rampersaud, R.; Berry, D.B.; Patel, S.; Oehler, A.; Lowe, J.K.; Kravitz, S.N.; et al. Evidence for alpha-synuclein prions causing multiple system atrophy in humans with parkinsonism. Proc. Natl. Acad. Sci. USA 2015, 112, E5308-E5317. [CrossRef] [PubMed] 
27. Woerman, A.L.; Watts, J.C.; Aoyagi, A.; Giles, K.; Middleton, L.T.; Prusiner, S.B. Alpha-synuclein: Multiple system atrophy prions. Cold Spring Harb. Perspect. Med. 2018, 8, a024588. [CrossRef]

28. Woerman, A.L.; Oehler, A.; Kazmi, S.A.; Lee, J.; Halliday, G.M.; Middleton, L.T.; Gentleman, S.M.; Mordes, D.A.; Spina, S.; Grinberg, L.T.; et al. Multiple system atrophy prions retain strain specificity after serial propagation in two different $\operatorname{Tg}\left(\mathrm{SNCA}^{*} \mathrm{~A} 53 \mathrm{~T}\right)$ mouse lines. Acta Neuropathol. 2019, 137, 437-454. [CrossRef]

29. Watts, J.C.; Giles, K.; Oehler, A.; Middleton, L.; Dexter, D.T.; Gentleman, S.M.; DeArmond, S.J.; Prusiner, S.B. Transmission of multiple system atrophy prions to transgenic mice. Proc. Natl. Acad. Sci. USA 2013, 110, 19555-19560. [CrossRef]

30. Chu, Y.; Kordower, J.H. The prion hypothesis of Parkinson's disease. Curr. Neurol. Neurosci. Rep. 2015, 15, 28. [CrossRef]

31. Ma, J.; Gao, J.; Wang, J.; Xie, A. Prion-like mechanisms in Parkinson's disease. Front. Neurosci. 2019, 13, 552. [CrossRef] [PubMed]

32. Melki, R. Alpha-synuclein and the prion hypothesis in Parkinson's disease. Rev. Neurol. 2018, 174, 644-652. [CrossRef]

33. Olanow, C.W. Do prions cause Parkinson disease? The evidence accumulates. Ann. Neurol. 2014, 75, 331-333. [CrossRef]

34. Rey, N.L.; George, S.; Brundin, P. Review: Spreading the word: Precise animal models and validated methods are vital when evaluating prion-like behaviour of alpha-synuclein. Neuropathol. Appl. Neurobiol. 2016, 42, 51-76. [CrossRef] [PubMed]

35. Tamguney, G.; Korczyn, A.D. A critical review of the prion hypothesis of human synucleinopathies. Cell Tissue Res. 2018, 373, 213-220. [CrossRef] [PubMed]

36. Leak, R.K.; Frosch, M.P.; Beach, T.G.; Halliday, G.M. Alpha-synuclein: Prion or prion-like? Acta Neuropathol. 2019, 138, 509-514. [CrossRef] [PubMed]

37. Wenning, G.; Trojanowski, J.Q.; Kaufmann, H.; Wisniewski, T.; Rocca, W.A.; Low, P.A. Is multiple system atrophy an infectious disease? Ann. Neurol. 2018, 83, 10-12. [CrossRef]

38. Meissner, W.G.; Fernagut, P.O.; Dehay, B.; Peran, P.; Traon, A.P.; Foubert-Samier, A.; Lopez Cuina, M.; Bezard, E.; Tison, F.; Rascol, O. Multiple system atrophy: Recent developments and future perspectives. Mov. Disord. 2019, 34, 1629-1642. [CrossRef]

39. Scialò, C.; De Cecco, E.; Manganotti, P.; Legname, G. Prion and prion-like protein strains: Deciphering the molecular basis of heterogeneity in neurodegeneration. Viruses 2019, 11, 261. [CrossRef]

40. Hass, E.W.; Sorrentino, Z.A.; Lloyd, G.M.; McFarland, N.R.; Prokop, S.; Giasson, B.I. Robust a-synuclein pathology in select brainstem neuronal populations is a potential instigator of multiple system atrophy. Acta Neuropathol. Commun. 2021, 9, 80. [CrossRef]

41. Hass, E.W.; Sorrentino, Z.A.; Xia, Y.; Lloyd, G.M.; Trojanowski, J.Q.; Prokop, S.; Giasson, B.I. Disease-, region- and cell type specific diversity of alpha-synuclein carboxy terminal truncations in synucleinopathies. Acta Neuropathol. Commun. 2021, 9, 146. [CrossRef]

42. Uchihara, T.; Giasson, B.I. Propagation of alpha-synuclein pathology: Hypotheses, discoveries, and yet unresolved questions from experimental and human brain studies. Acta Neuropathol. 2016, 131, 49-73. [CrossRef] [PubMed]

43. Makin, S. Pathology: The prion principle. Nature 2016, 538, S13-S16. [CrossRef]

44. Brundin, P.; Melki, R. Prying into the prion hypothesis for Parkinson's disease. J. Neurosci. 2017, 37, 9808-9818. [CrossRef] [PubMed]

45. Surmeier, D.J.; Obeso, J.A.; Halliday, G.M. Parkinson's disease is not simply a prion disorder. J. Neurosci. 2017, 37, 9799-9807. [CrossRef] [PubMed]

46. Siddique, Y.H. Does human alpha synuclein behave like prions? CNS Neurol. Disord. Drug Targets 2021. [CrossRef]

47. Zheng, H.; Shi, C.; Luo, H.; Fan, L.; Yang, Z.; Hu, X.; Zhang, Z.; Zhang, S.; Hu, Z.; Fan, Y.; et al. Alpha-synuclein in Parkinson's disease: Does a prion-like mechanism of propagation from periphery to the brain play a role? Neuroscientist 2021, 27, 367-387. [CrossRef]

48. Woerman, A.L.; Kazmi, S.A.; Patel, S.; Aoyagi, A.; Oehler, A.; Widjaja, K.; Mordes, D.A.; Olson, S.H.; Prusiner, S.B. Familial Parkinson's point mutation abolishes multiple system atrophy prion replication. Proc. Natl. Acad. Sci. USA 2018, 115, 409-414. [CrossRef]

49. Watts, J.C. Calling alpha-synuclein a prion is scientifically justifiable. Acta Neuropathol. 2019, 138, 505-508. [CrossRef]

50. Prusiner, S.B. Novel proteinaceous infectious particles cause scrapie. Science 1982, 216, 136-144. [CrossRef] [PubMed]

51. Prusiner, S.B. Biology and genetics of prions causing neurodegeneration. Annu. Rev. Genet. 2013, 47, 601-623. [CrossRef]

52. Colin, M.; Dujardin, S.; Schraen-Maschke, S.; Meno-Tetang, G.; Duyckaerts, C.; Courade, J.P.; Buee, L. From the prion-like propagation hypothesis to therapeutic strategies of anti-tau immunotherapy. Acta Neuropathol. 2020, 139, 3-25. [CrossRef] [PubMed]

53. Ghaemmaghami, S. Biology and genetics of PrP prion strains. In Prion Diseases; Prusiner, S.B., Ed.; Cold Spring Harbor Laboratory Press: Long Island, NY, USA, 2017; pp. 45-56.

54. Tanaka, M.; Chien, P.; Naber, N.; Cooke, R.; Weissman, J.S. Conformational variations in an infectious protein determine prion strain differences. Nature 2004, 428, 323-328. [CrossRef]

55. Telling, G.C.; Parchi, P.; DeArmond, S.J.; Cortelli, P.; Montagna, P.; Gabizon, R.; Mastrianni, J.; Lugaresi, E.; Gambetti, P.; Prusiner, S.B. Evidence for the conformation of the pathologic isoform of the prion protein enciphering and propagating prion diversity. Science 1996, 274, 2079-2082. [CrossRef] [PubMed]

56. Lau, A.; So, R.W.; Lau, H.H.; Sang, J.C.; Ruiz-Riquelme, A.; Fleck, S.C.; Stuart, E.; Menon, S.; Visanji, N.P.; Meisl, G.; et al. Alpha-synuclein strains target distinct brain regions and cell types. Nat. Neurosci. 2020, 23, 21-31. [CrossRef] 
57. Prusiner, S.B. An introduction to prion diseases. In Prion Diseases; Prusiner, S.B., Ed.; Cold Spring Harbor Laboratory Press: Long Island, NY, USA, 2017; pp. 1-29.

58. Woerman, A.L. Strain diversity in neurodegenerative disease: An argument for a personalized medicine approach to diagnosis and treatment. Acta Neuropathol. 2021, 142, 1-3. [CrossRef] [PubMed]

59. Uemura, N.; Uemura, M.T.; Luk, K.C.; Lee, V.M.; Trojanowski, J.Q. Cell-to-cell transmission of tau and alpha-synuclein. Trends Mol. Med. 2020, 26, 936-952. [CrossRef]

60. Holec, S.A.; Woerman, A.L. Evidence of distinct alpha-synuclein strains underlying disease heterogeneity. Acta Neuropathol. 2020, 142, 73-86. [CrossRef] [PubMed]

61. Sorrentino, Z.A.; Giasson, B.I. The emerging role of alpha-synuclein truncation in aggregation and disease. J. Biol. Chem. 2020, 295, 10224-10244. [CrossRef] [PubMed]

62. Schweighauser, M.; Shi, Y.; Tarutani, A.; Kametani, F.; Murzin, A.G.; Ghetti, B.; Matsubara, T.; Tomita, T.; Ando, T.; Hasegawa, K.; et al. Structures of alpha-synuclein filaments from multiple system atrophy. Nature 2020, 585, 464-469. [CrossRef] [PubMed]

63. Liu, D.; Guo, J.J.; Su, J.H.; Svanbergsson, A.; Yuan, L.; Haikal, C.; Li, W.; Gouras, G.; Li, J.Y. Differential seeding and propagating efficiency of a-synuclein strains generated in different conditions. Transl. Neurodegener. 2021, 10, 20. [CrossRef] [PubMed]

64. Van der Perren, A.; Gelders, G.; Fenyi, A.; Bousset, L.; Brito, F.; Peelaerts, W.; Van den Haute, C.; Gentleman, S.; Melki, R.; Baekelandt, V. The structural differences between patient-derived alpha-synuclein strains dictate characteristics of Parkinson's disease, multiple system atrophy and dementia with Lewy bodies. Acta Neuropathol. 2020, 139, 977-1000. [CrossRef]

65. Guo, J.L.; Lee, V.M. Cell-to-cell transmission of pathogenic proteins in neurodegenerative diseases. Nat. Med. 2014, 20, 130-138. [CrossRef]

66. Ugalde, C.L.; Finkelstein, D.I.; Lawson, V.A.; Hill, A.F. Pathogenic mechanisms of prion protein, amyloid-beta and alpha-synuclein misfolding: The prion concept and neurotoxicity of protein oligomers. J. Neurochem. 2016, 139, 162-180. [CrossRef]

67. Chu, Y.; Muller, S.; Tavares, A.; Barret, O.; Alagille, D.; Seibyl, J.; Tamagnan, G.; Marek, K.; Luk, K.C.; Trojanowski, J.Q.; et al. Intrastriatal alpha-synuclein fibrils in monkeys: Spreading, imaging and neuropathological changes. Brain 2019, 142, 3565-3579. [CrossRef]

68. Luk, K.C.; Kehm, V.; Carroll, J.; Zhang, B.; O’Brien, P.; Trojanowski, J.Q.; Lee, V.M. Pathological alpha-synuclein transmission initiates Parkinson-like neurodegeneration in nontransgenic mice. Science 2012, 338, 949-953. [CrossRef]

69. Bassil, F.; Brown, H.J.; Pattabhiraman, S.; Iwasyk, J.E.; Maghames, C.M.; Meymand, E.S.; Cox, T.O.; Riddle, D.M.; Zhang, B.; Trojanowski, J.Q.; et al. Amyloid-beta (Abeta) plaques promote seeding and spreading of alpha-synuclein and tau in a mouse model of Lewy body disorders with Abeta pathology. Neuron 2020, 105, 260-275.e6. [CrossRef]

70. Badiola, N.; de Oliveira, R.M.; Herrera, F.; Guardia-Laguarta, C.; Gonçalves, S.A.; Pera, M.; Suárez-Calvet, M.; Clarimon, J.; Outeiro, T.F.; Lleó, A. Tau enhances alpha-synuclein aggregation and toxicity in cellular models of synucleinopathy. PLoS ONE 2011, 6, e26609. [CrossRef]

71. Masuda-Suzukake, M.; Hasegawa, M. Prion-like propagation of pathological alpha-synuclein in vivo. Yakugaku Zasshi 2019, 139, 1007-1013. [CrossRef] [PubMed]

72. Bernis, M.E.; Babila, J.T.; Breid, S.; Wusten, K.A.; Wullner, U.; Tamguney, G. Prion-like propagation of human brain-derived alpha-synuclein in transgenic mice expressing human wild-type alpha-synuclein. Acta Neuropathol. Commun. $2015,3,75$. [CrossRef] [PubMed]

73. Candelise, N.; Schmitz, M.; Llorens, F.; Villar-Pique, A.; Cramm, M.; Thom, T.; da Silva Correia, S.M.; da Cunha, J.E.; Mobius, W.; Outeiro, T.F.; et al. Seeding variability of different alpha synuclein strains in synucleinopathies. Ann. Neurol. 2019, 85, 691-703. [CrossRef] [PubMed]

74. Shearer, L.J.; Petersen, N.O.; Woodside, M.T. Internalization of alpha-synuclein oligomers into SH-SY5Y cells. Biophys. J. 2021, 120,877-885. [CrossRef]

75. Oueslati, A.; Ximerakis, M.; Vekrellis, K. Protein transmission, seeding and degradation: Key steps for a-synuclein prion-like propagation. Exp. Neurobiol. 2014, 23, 324-336. [CrossRef] [PubMed]

76. Trinkaus, V.A.; Riera-Tur, I.; Martínez-Sánchez, A.; Bäuerlein, F.J.; Guo, Q.; Arzberger, T.; Baumeister, W.; Dudanova, I.; Hipp, M.S.; Hartl, F.U.; et al. In situ architecture of neuronal alpha-synuclein inclusions. Nat. Commun. 2021, 12, 2110. [CrossRef]

77. Jan, A.; Gonçalves, N.P.; Vaegter, C.B.; Jensen, P.H.; Ferreira, N. The prion-like spreading of alpha-synuclein in Parkinson's disease: Update on models and hypotheses. Int. J. Mol. Sci. 2021, 22, 8338. [CrossRef]

78. Thom, T.; Schmitz, M.; Fischer, A.L.; Correia, A.; Correia, S.; Llorens, F.; Pique, A.V.; Möbius, W.; Domingues, R.; Zafar, S.; et al. Cellular prion protein mediates alpha-synuclein uptake, localization, and toxicity in vitro and in vivo. Mov. Disord. 2021. [CrossRef]

79. Hijaz, B.A.; Volpicelli-Daley, L.A. Initiation and propagation of alpha-synuclein aggregation in the nervous system. Mol. Neurodegener. 2020, 15, 19. [CrossRef]

80. Ayers, J.I.; Paras, N.A.; Prusiner, S.B. Expanding spectrum of prion diseases. Emerg. Top. Life Sci. 2020, 4, $155-167$.

81. Scheckel, C.; Aguzzi, A. Prions, prionoids and protein misfolding disorders. Nat. Rev. Genet. 2018, 19, 405-418. [CrossRef]

82. Kraus, A.; Groveman, B.R.; Caughey, B. Prions and the potential transmissibility of protein misfolding diseases. Annu. Rev. Microbiol. 2013, 67, 543-564. [CrossRef]

83. Walker, L.C.; Jucker, M. Neurodegenerative diseases: Expanding the prion concept. Annu. Rev. Neurosci. 2015, 38, 87-103. [CrossRef] [PubMed] 
84. Collinge, J. Mammalian prions and their wider relevance in neurodegenerative diseases. Nature 2016, 539, 217-226. [CrossRef] [PubMed]

85. Irwin, D.J.; Abrams, J.Y.; Schonberger, L.B.; Leschek, E.W.; Mills, J.L.; Lee, V.M.; Trojanowski, J.Q. Evaluation of potential infectivity of Alzheimer and Parkinson disease proteins in recipients of cadaver-derived human growth hormone. JAMA Neurol. 2013, 70, 462-468. [CrossRef] [PubMed]

86. Caughey, B.; Kraus, A. Transmissibility versus Pathogenicity of Self-Propagating Protein Aggregates. Viruses 2019, 11, 1044. [CrossRef]

87. Ritchie, D.L.; Barria, M.A. Prion diseases: A unique transmissible agent or a model for neurodegenerative diseases? Biomolecules 2021, 11, 207. [CrossRef]

88. Schwarzman, A.L.; Senkevich, K.A.; Emelyanov, A.K.; Pchelina, S.N. Prion properties of alpha-synuclein. Mol. Biol. 2019, 53, 335-341. [CrossRef]

89. Watts, J.C.; Prusiner, S.B. Beta-Amyloid prions and the pathobiology of Alzheimer's disease. Cold Spring Harb. Perspect. Med. 2018, 8, a023507. [CrossRef]

90. Aguzzi, A. Cell biology: Beyond the prion principle. Nature 2009, 459, 924-925. [CrossRef]

91. Verma, A. Prions, prion-like prionoids, and neurodegenerative disorders. Ann. Indian Acad Neurol. 2016, 19, 169-174. [CrossRef]

92. Wells, C.; Brennan, S.E.; Keon, M.; Saksena, N.K. Prionoid proteins in the pathogenesis of neurodegenerative diseases. Front. Mol. Neurosci. 2019, 12, 271. [CrossRef]

93. Mavroeidi, P.; Xilouri, M. Neurons and glia interplay in alpha-synucleinopathies. Int. J. Mol. Sci. 2021, 22, 4994. [CrossRef]

94. Jucker, M.; Walker, L.C. Self-propagation of pathogenic protein aggregates in neurodegenerative diseases. Nature 2013, 501, 45-51. [CrossRef]

95. Prusiner, S.B. Cell biology. A unifying role for prions in neurodegenerative diseases. Science 2012, 336, 1511-1513. [CrossRef]

96. Duyckaerts, C.; Clavaguera, F.; Potier, M.C. The prion-like propagation hypothesis in Alzheimer's and Parkinson's disease. Curr. Opin. Neurol. 2019, 32, 266-271. [CrossRef] [PubMed]

97. Heras-Garvin, A.; Stefanova, N. From synaptic protein to prion: The long and controversial journey of alpha-synuclein. Front. Synaptic Neurosci. 2020, 12, 584536. [CrossRef] [PubMed]

98. Goedert, M.; Masuda-Suzukake, M.; Falcon, B. Like prions: The propagation of aggregated tau and alpha-synuclein in neurodegeneration. Brain 2017, 140, 266-278. [CrossRef] [PubMed]

99. Kordower, J.H.; Chu, Y.; Hauser, R.A.; Freeman, T.B.; Olanow, C.W. Lewy body-like pathology in long-term embryonic nigral transplants in Parkinson's disease. Nat. Med. 2008, 14, 504-506. [CrossRef] [PubMed]

100. Li, J.Y.; Englund, E.; Holton, J.L.; Soulet, D.; Hagell, P.; Lees, A.J.; Lashley, T.; Quinn, N.P.; Rehncrona, S.; Bjorklund, A.; et al. Lewy bodies in grafted neurons in subjects with Parkinson's disease suggest host-to-graft disease propagation. Nat. Med. 2008, 14, 501-503. [CrossRef]

101. El-Agnaf, O.M.; Salem, S.A.; Paleologou, K.E.; Cooper, L.J.; Fullwood, N.J.; Gibson, M.J.; Curran, M.D.; Court, J.A.; Mann, D.M.; Ikeda, S.; et al. Alpha-synuclein implicated in Parkinson's disease is present in extracellular biological fluids, including human plasma. FASEB J. 2003, 17, 1945-1947. [CrossRef]

102. Hasegawa, M.; Nonaka, T.; Masuda-Suzukake, M. Alpha-synuclein: Experimental pathology. Cold Spring Harb. Perspect. Med. 2016, 6, a024273. [CrossRef]

103. Henderson, M.X.; Cornblath, E.J.; Darwich, A.; Zhang, B.; Brown, H.; Gathagan, R.J.; Sandler, R.M.; Bassett, D.S.; Trojanowski, J.Q.; Lee, V.M. Spread of alpha-synuclein pathology through the brain connectome is modulated by selective vulnerability and predicted by network analysis. Nat. Neurosci. 2019, 22, 1248-1257. [CrossRef]

104. Dehay, B.; Vila, M.; Bezard, E.; Brundin, P.; Kordower, J.H. Alpha-synuclein propagation: New insights from animal models. Mov. Disord. 2016, 31, 161-168. [CrossRef]

105. Hasegawa, M.; Nonaka, T.; Masuda-Suzukake, M. Prion-like mechanisms and potential therapeutic targets in neurodegenerative disorders. Pharmacol. Ther. 2017, 172, 22-33. [CrossRef] [PubMed]

106. Stopschinski, B.E.; Diamond, M.I. The prion model for progression and diversity of neurodegenerative diseases. Lancet Neurol. 2017, 16, 323-332. [CrossRef]

107. Valdinocci, D.; Radford, R.A.; Siow, S.M.; Chung, R.S.; Pountney, D.L. Potential modes of intercellular alpha-synuclein transmission. Int. J. Mol. Sci. 2017, 18, 469. [CrossRef] [PubMed]

108. Desplats, P.; Lee, H.J.; Bae, E.J.; Patrick, C.; Rockenstein, E.; Crews, L.; Spencer, B.; Masliah, E.; Lee, S.J. Inclusion formation and neuronal cell death through neuron-to-neuron transmission of alpha-synuclein. Proc. Natl. Acad. Sci. USA 2009, 106, 13010-13015. [CrossRef] [PubMed]

109. Woerman, A.L.; Stohr, J.; Aoyagi, A.; Rampersaud, R.; Krejciova, Z.; Watts, J.C.; Ohyama, T.; Patel, S.; Widjaja, K.; Oehler, A.; et al. Propagation of prions causing synucleinopathies in cultured cells. Proc. Natl. Acad. Sci. USA 2015, 112, E4949-E4958. [CrossRef]

110. Dujardin, S.; Lécolle, K.; Caillierez, R.; Bégard, S.; Zommer, N.; Lachaud, C.; Carrier, S.; Dufour, N.; Aurégan, G.; Winderickx, J.; et al. Neuron-to-neuron wild-type tau protein transfer through a trans-synaptic mechanism: Relevance to sporadic tauopathies. Acta Neuropathol. Commun. 2014, 2, 14. [CrossRef]

111. Clavaguera, F.; Akatsu, H.; Fraser, G.; Crowther, R.A.; Frank, S.; Hench, J.; Probst, A.; Winkler, D.T.; Reichwald, J.; Staufenbiel, M.; et al. Brain homogenates from human tauopathies induce tau inclusions in mouse brain. Proc. Natl. Acad. Sci. USA 2013, 110, 9535-9540. [CrossRef] 
112. Clavaguera, F.; Lavenir, I.; Falcon, B.; Frank, S.; Goedert, M.; Tolnay, M. "Prion-like” templated misfolding in tauopathies. Brain Pathol. 2013, 23, 342-349. [CrossRef]

113. Olsson, T.T.; Klementieva, O.; Gouras, G.K. Prion-like seeding and nucleation of intracellular amyloid-beta. Neurobiol. Dis. 2018, 113, 1-10. [CrossRef] [PubMed]

114. Gomes, L.A.; Hipp, S.A.; Rijal Upadhaya, A.; Balakrishnan, K.; Ospitalieri, S.; Koper, M.J.; Largo-Barrientos, P.; Uytterhoeven, V.; Reichwald, J.; Rabe, S.; et al. Abeta-induced acceleration of Alzheimer-related tau-pathology spreading and its association with prion protein. Acta Neuropathol. 2019, 138, 913-941. [CrossRef]

115. Fornari, S.; Schäfer, A.; Kuhl, E.; Goriely, A. Spatially-extended nucleation-aggregation-fragmentation models for the dynamics of prion-like neurodegenerative protein-spreading in the brain and its connectome. J. Theor. Biol. 2020, 486, 110102. [CrossRef] [PubMed]

116. Masuda-Suzukake, M.; Nonaka, T.; Hosokawa, M.; Oikawa, T.; Arai, T.; Akiyama, H.; Mann, D.M.; Hasegawa, M. Prion-like spreading of pathological alpha-synuclein in brain. Brain 2013, 136, 1128-1138. [CrossRef]

117. Masuda-Suzukake, M.; Nonaka, T.; Hosokawa, M.; Kubo, M.; Shimozawa, A.; Akiyama, H.; Hasegawa, M. Pathological alpha-synuclein propagates through neural networks. Acta Neuropathol. Commun. 2014, 2, 88. [CrossRef] [PubMed]

118. Chung, H.K.; Ho, H.A.; Pérez-Acuña, D.; Lee, S.J. Modeling a-synuclein propagation with preformed fibril injections. J. Mov. Disord. 2019, 12, 139-151. [CrossRef]

119. Reyes, J.F.; Sackmann, C.; Hoffmann, A.; Svenningsson, P.; Winkler, J.; Ingelsson, M.; Hallbeck, M. Binding of a-synuclein oligomers to Cx32 facilitates protein uptake and transfer in neurons and oligodendrocytes. Acta Neuropathol. 2019, $138,23-47$. [CrossRef]

120. Ferreira, N.; Gram, H.; Sorrentino, Z.A.; Gregersen, E.; Schmidt, S.I.; Reimer, L.; Betzer, C.; Perez-Gozalbo, C.; Beltoja, M.; Nagaraj, M.; et al. Multiple system atrophy-associated oligodendroglial protein p $25 \alpha$ stimulates formation of novel $\alpha$-synuclein strain with enhanced neurodegenerative potential. Acta Neuropathol. 2021, 142, 87-115. [CrossRef]

121. Lohmann, S.; Bernis, M.E.; Tachu, B.J.; Ziemski, A.; Grigoletto, J.; Tamguney, G. Oral and intravenous transmission of alphasynuclein fibrils to mice. Acta Neuropathol. 2019, 138, 515-533. [CrossRef]

122. Sacino, A.N.; Brooks, M.; Thomas, M.A.; McKinney, A.B.; Lee, S.; Regenhardt, R.W.; McGarvey, N.H.; Ayers, J.I.; Notterpek, L.; Borchelt, D.R.; et al. Intramuscular injection of alpha-synuclein induces CNS alpha-synuclein pathology and a rapid-onset motor phenotype in transgenic mice. Proc. Natl. Acad. Sci. USA 2014, 111, 10732-10737. [CrossRef]

123. Breid, S.; Bernis, M.E.; Babila, J.T.; Garza, M.C.; Wille, H.; Tamguney, G. Neuroinvasion of alpha-synuclein prionoids after intraperitoneal and intraglossal inoculation. J. Virol. 2016, 90, 9182-9193. [CrossRef] [PubMed]

124. Ayers, J.I.; Brooks, M.M.; Rutherford, N.J.; Howard, J.K.; Sorrentino, Z.A.; Riffe, C.J.; Giasson, B.I. Robust central nervous system pathology in transgenic mice following peripheral injection of alpha-synuclein fibrils. J. Virol. 2017, 91, e02095-16. [CrossRef]

125. Van Den Berge, N.; Ferreira, N.; Gram, H.; Mikkelsen, T.W.; Alstrup, A.K.; Casadei, N.; Tsung-Pin, P.; Riess, O.; Nyengaard, J.R.; Tamguney, G.; et al. Evidence for bidirectional and trans-synaptic parasympathetic and sympathetic propagation of alpha-synuclein in rats. Acta Neuropathol. 2019, 138, 535-550. [CrossRef] [PubMed]

126. Kim, S.; Kwon, S.H.; Kam, T.I.; Panicker, N.; Karuppagounder, S.S.; Lee, S.; Lee, J.H.; Kim, W.R.; Kook, M.; Foss, C.A.; et al. Transneuronal propagation of pathologic alpha-synuclein from the gut to the brain models Parkinson's disease. Neuron 2019, 103, 627-641.e7. [CrossRef] [PubMed]

127. Breen, D.P.; Halliday, G.M.; Lang, A.E. Gut-brain axis and the spread of alpha-synuclein pathology: Vagal highway or dead end? Mov. Disord. 2019, 34, 307-316. [CrossRef]

128. Recasens, A.; Dehay, B.; Bove, J.; Carballo-Carbajal, I.; Dovero, S.; Perez-Villalba, A.; Fernagut, P.O.; Blesa, J.; Parent, A.; Perier, C.; et al. Lewy body extracts from Parkinson disease brains trigger alpha-synuclein pathology and neurodegeneration in mice and monkeys. Ann. Neurol. 2014, 75, 351-362. [CrossRef]

129. Kawakami, I.; Motoda, A.; Hashimoto, M.; Shimozawa, A.; Masuda-Suzukake, M.; Ohtani, R.; Takase, M.; Kumashiro, M.; Samejima, K.; Hasegawa, M. Progression of phosphorylated a-synuclein in Macaca fuscata. Brain Pathol. 2021,31, e12952. [CrossRef] [PubMed]

130. Shimozawa, A.; Ono, M.; Takahara, D.; Tarutani, A.; Imura, S.; Masuda-Suzukake, M.; Higuchi, M.; Yanai, K.; Hisanaga, S.I.; Hasegawa, M. Propagation of pathological alpha-synuclein in marmoset brain. Acta Neuropathol. Commun. 2017, 5, 12. [CrossRef] [PubMed]

131. Ogata, J.; Takemoto, D.; Shimonaka, S.; Imai, Y.; Hattori, N. Alpha-synuclein seeding assay using cultured cells. Methods Mol. Biol. 2021, 2322, 27-39.

132. Aguzzi, A.; Lakkaraju, A.K. Cell biology of prions and prionoids: A status report. Trends Cell Biol. 2016, 26, 40-51. [CrossRef]

133. Peng, C.; Gathagan, R.J.; Covell, D.J.; Medellin, C.; Stieber, A.; Robinson, J.L.; Zhang, B.; Pitkin, R.M.; Olufemi, M.F.; Luk, K.C.; et al. Cellular milieu imparts distinct pathological alpha-synuclein strains in alpha-synucleinopathies. Nature 2018, 557, 558-563. [CrossRef]

134. Peng, C.; Gathagan, R.J.; Lee, V.M. Distinct alpha-synuclein strains and implications for heterogeneity among alphasynucleinopathies. Neurobiol. Dis. 2018, 109, 209-218. [CrossRef]

135. Uemura, N.; Uemura, M.T.; Lo, A.; Bassil, F.; Zhang, B.; Luk, K.C.; Lee, V.M.; Takahashi, R.; Trojanowski, J.Q. Slow progressive accumulation of oligodendroglial alpha-synuclein (alpha-syn) pathology in synthetic alpha-syn fibril-induced mouse models of synucleinopathy. J. Neuropathol. Exp. Neurol. 2019, 78, 877-890. [CrossRef] [PubMed] 
136. Miller, D.W.; Johnson, J.M.; Solano, S.M.; Hollingsworth, Z.R.; Standaert, D.G.; Young, A.B. Absence of alpha-synuclein mRNA expression in normal and multiple system atrophy oligodendroglia. J. Neural Transm. 2005, 112, 1613-1624. [CrossRef] [PubMed]

137. Yamasaki, T.R.; Holmes, B.B.; Furman, J.L.; Dhavale, D.D.; Su, B.W.; Song, E.S.; Cairns, N.J.; Kotzbauer, P.T.; Diamond, M.I. Parkinson's disease and multiple system atrophy have distinct alpha-synuclein seed characteristics. J. Biol. Chem. 2019, 294, 1045-1058. [CrossRef]

138. Lövestam, S.; Schweighauser, M.; Matsubara, T.; Murayama, S.; Tomita, T.; Ando, T.; Hasegawa, K.; Yoshida, M.; Tarutani, A.; Hasegawa, M.; et al. Seeded assembly in vitro does not replicate the structures of a-synuclein filaments from multiple system atrophy. FEBS Openbio 2021, 11, 999-1013. [CrossRef]

139. Giasson, B.I.; Duda, J.E.; Quinn, S.M.; Zhang, B.; Trojanowski, J.Q.; Lee, V.M. Neuronal alpha-synucleinopathy with severe movement disorder in mice expressing A53T human alpha-synuclein. Neuron 2002, 34, 521-533. [CrossRef]

140. Peelaerts, W.; Bousset, L.; Van der Perren, A.; Moskalyuk, A.; Pulizzi, R.; Giugliano, M.; Van den Haute, C.; Melki, R.; Baekelandt, V. Alpha-synuclein strains cause distinct synucleinopathies after local and systemic administration. Nature 2015, 522, 340-344. [CrossRef]

141. Bousset, L.; Melki, R. Infectious properties of protein aggregates involved in neurodegenerative diseases. Biol. Aujourdhui 2013, 207, 55-59. [CrossRef]

142. Peelaerts, W.; Baekelandt, V. Alpha-synuclein strains and the variable pathologies of synucleinopathies. J. Neurochem. 2016, 139 (Suppl. S1), 256-274. [CrossRef] [PubMed]

143. Tarutani, A.; Hasegawa, M. Prion-like propagation of alpha-synuclein in neurodegenerative diseases. Prog. Mol. Biol. Transl. Sci. 2019, 168, 323-348.

144. Fearon, C.; Farrell, M.A. Disease-specific strains of alpha-synuclein in multiple system atrophy and Parkinson's disease: But why? Mov. Disord. 2020, 35, 756-757. [CrossRef] [PubMed]

145. Shahnawaz, M.; Mukherjee, A.; Pritzkow, S.; Mendez, N.; Rabadia, P.; Liu, X.; Hu, B.; Schmeichel, A.; Singer, W.; Wu, G.; et al. Discriminating alpha-synuclein strains in Parkinson's disease and multiple system atrophy. Nature 2020, 578, 273-277. [CrossRef] [PubMed]

146. Dhillon, J.S.; Trejo-Lopez, J.A.; Riffe, C.; Levites, Y.; Sacino, A.N.; Borchelt, D.R.; Yachnis, A.Y.; Giasson, B.I. Comparative analyses of the in vivo induction and transmission of alpha-synuclein pathology in transgenic mice by MSA brain lysate and recombinant alpha-synuclein fibrils. Acta Neuropathol. Commun. 2019, 7, 80. [CrossRef]

147. Sargent, D.; Verchere, J.; Lazizzera, C.; Gaillard, D.; Lakhdar, L.; Streichenberger, N.; Morignat, E.; Betemps, D.; Baron, T. 'Prion-like' propagation of the synucleinopathy of M83 transgenic mice depends on the mouse genotype and type of inoculum. $J$. Neurochem. 2017, 143, 126-135. [CrossRef]

148. Krejciova, Z.; Carlson, G.A.; Giles, K.; Prusiner, S.B. Replication of multiple system atrophy prions in primary astrocyte cultures from transgenic mice expressing human alpha-synuclein. Acta Neuropathol. Commun. 2019, 7, 81. [CrossRef]

149. Sacino, A.N.; Ayers, J.I.; Brooks, M.M.; Chakrabarty, P.; Hudson, V.J., 3rd; Howard, J.K.; Golde, T.E.; Giasson, B.I.; Borchelt, D.R. Non-prion-type transmission in A53T alpha-synuclein transgenic mice: A normal component of spinal homogenates from naive non-transgenic mice induces robust alpha-synuclein pathology. Acta Neuropathol. 2016, 131, 151-154. [CrossRef]

150. Sanders, D.W.; Kaufman, S.K.; DeVos, S.L.; Sharma, A.M.; Mirbaha, H.; Li, A.; Barker, S.J.; Foley, A.C.; Thorpe, J.R.; Serpell, L.C.; et al. Distinct tau prion strains propagate in cells and mice and define different tauopathies. Neuron 2014, 82, 1271-1288. [CrossRef]

151. Aulic, S.; Masperone, L.; Narkiewicz, J.; Isopi, E.; Bistaffa, E.; Ambrosetti, E.; Pastore, B.; De Cecco, E.; Scaini, D.; Zago, P.; et al. Alpha-Synuclein amyloids hijack prion protein to gain cell entry, facilitate cell-to-cell spreading and block prion replication. Sci. Rep. 2017, 7, 10050. [CrossRef]

152. De Cecco, E.; Legname, G. The role of the prion protein in the internalization of alpha-synuclein amyloids. Prion 2018, $12,23-27$. [CrossRef] [PubMed]

153. Haik, S.; Privat, N.; Adjou, K.T.; Sazdovitch, V.; Dormont, D.; Duyckaerts, C.; Hauw, J.J. Alpha-synuclein-immunoreactive deposits in human and animal prion diseases. Acta Neuropathol. 2002, 103, 516-520.

154. La Vitola, P.; Beeg, M.; Balducci, C.; Santamaria, G.; Restelli, E.; Colombo, L.; Caldinelli, L.; Pollegioni, L.; Gobbi, M.; Chiesa, R.; et al. Cellular prion protein neither binds to alpha-synuclein oligomers nor mediates their detrimental effects. Brain 2019, 142, 249-254. [CrossRef]

155. Gelpi, E.; Colom-Cadena, M. Oligomers: A hot topic for neurodegeneration and a note of caution for experimental models. Brain 2019, 142, 228-230. [CrossRef]

156. Visanji, N.P.; Lang, A.E.; Kovacs, G.G. Beyond the synucleinopathies: Alpha synuclein as a driving force in neurodegenerative comorbidities. Transl. Neurodegener. 2019, 8, 28. [CrossRef] [PubMed]

157. Bistaffa, E.; Rossi, M.; De Luca, C.M.G.; Cazzaniga, F.; Carletta, O.; Campagnani, I.; Tagliavini, F.; Legname, G.; Giaccone, G.; Moda, F. Prion efficiently replicates in alpha-synuclein knockout mice. Mol. Neurobiol. 2019, 56, 7448-7457. [CrossRef] [PubMed]

158. Bartz, J.C. Environmental and host factors that contribute to prion strain evolution. Acta Neuropathol. 2021, 142, 5-16. [CrossRef] [PubMed]

159. Chelban, V.; Manole, A.; Pihlstrom, L.; Schottlaender, L.; Efthymiou, S.; O'Conner, E.; Meissner, W.G.; Holton, J.L.; Houlden, H. Analysis of the prion protein gene in multiple system atrophy. Neurobiol. Aging 2017, 49, 216.e15-216.e18. [CrossRef] 
160. De Pablo-Fernandez, E.; Cerdan Santacruz, D.; Warner, T.T.; Holton, J.L. No evidence of iatrogenic human transmission in autopsy confirmed multiple system atrophy. Mov. Disord. 2018, 33, 1183-1184. [CrossRef] [PubMed]

161. Rajput, A.H.; Ferguson, L.W.; Robinson, C.A.; Guella, I.; Farrer, M.J.; Rajput, A. Conjugal parkinsonism-Clinical, pathology and genetic study. No evidence of person-to-person transmission. Parkinsonism Relat. Disord. 2016, 31, 87-90. [CrossRef]

162. Coon, E.A.; Rocca, W.; Melson, C.S.; Ahlskog, J.E.; Matsumoto, J.Y.; Low, P.A.; Singer, W. Conjugal multiple system atrophy: Chance, shared risk factors, or evidence of transmissibility? Parkinsonism Relat. Disord. 2019, 67, 10-13. [CrossRef]

163. Asher, D.M.; Belay, E.; Bigio, E.; Brandner, S.; Brubaker, S.A.; Caughey, B.; Clark, B.; Damon, I.; Diamond, M.; Freund, M.; et al. Risk of transmissibility from neurodegenerative disease-associated proteins: Experimental knowns and unknowns. J. Neuropathol. Exp. Neurol. 2020, 79, 1141-1146. [CrossRef]

164. Rey, N.L.; George, S.; Steiner, J.A.; Madaj, Z.; Luk, K.C.; Trojanowski, J.Q.; Lee, V.M.; Brundin, P. Spread of aggregates after olfactory bulb injection of alpha-synuclein fibrils is associated with early neuronal loss and is reduced long term. Acta Neuropathol. 2018, 135, 65-83. [CrossRef] [PubMed] 